\title{
Rediscovering RNA
}

\author{
ANNA MARIE PYLE \\ Department of Molecular, Cellular and Developmental Biology; Department of Chemistry; Howard Hughes Medical Institute; Yale University, New \\ Haven, Connecticut 06520, USA
}

One of the things that I find intriguing about RNA science is that each successive generation of investigators seems to rediscover RNA, and to harbor the conviction that they have revealed its significance and unique attributes for the very first time. This is a good thing - as each generation of RNA scientists feels "ownership" for a fundamental aspect of our understanding, and this has resulted in a collegial, multigenerational and continually exciting field of research. Either because I am getting old or I have spent too many years teaching Molecular Biology to undergraduates, I enjoy looking for the strands that connect the discoveries of the present with insights from the past. While we tend to think of RNA as a "new science," nothing could be farther from the truth. Olke Uhlenbeck used to tell me that "we already learned everything from tRNA," and I just thought he was being grumpy. But in many cases, he was right. We have come a long way in the last 70 years, when RNA science bloomed in places like postwar Cambridge and Manhattan, and I'd like to share a few of the strands connecting past and present that come to my mind when I think about my favorite, but by no means comprehensive, milestones in RNA science:

\section{Discovering the prevalence and significance of long noncoding RNAs (or alternatively, 'That RNA is not junk')}

To me, one of the greatest findings in the last 20 years was the demonstration that we make a lot of RNA, much more RNA than we ever imagined. In 2007, ENCODE investigators demonstrated that, in transcribing almost our entire genome, we churn out all kinds of RNAs with the potential to do things that are known, barely understood, and not even politely imagined. Most of this RNA does not encode for protein, and has been dubbed "noncoding RNA." It is fashionable to call it "dark matter." In some cases, the transcripts are incredibly long, and they are increasingly implicated in processes where, even a few years ago, we thought RNA had no business: activation and deactivation of chromosomes, epigenetic control, regulation of translation, and many other pro-

Corresponding author: anna.pyle@yale.edu

Article and publication date are at http://www.rnajournal.org/cgi/doi/ $10.1261 /$ rna.050807.115. Freely available online through the RNA Open Access option. cesses. The discovery of long intergenic noncoding RNAs (lincRNAs) by Howard Chang and John Rinn, particularly in concert with complementary whole-genome analyses of RNA by investigators such as Jonathon Weissman and Eric Lander, include some of the most important biological discoveries of our time.

However, it in no way diminishes their accomplishment to point out that long noncoding RNAs, and their dazzlingly diverse functions, have been known for decades and are not, in fact, so dark. Joan Steitz was one of the first to exclaim "Hey, that noncoding RNA is not junk," when she discovered the abundant small nuclear RNAs (snRNAs) and small nucleolar RNAs (snoRNA precursors) and showed that they were not informational tapes, but involved in RNA processing. In fact, the first RNA molecules to be discovered and physically characterized were giant noncoding RNAs: Ribosomal RNA was so abundant that early investigators couldn't even find mRNA for a very long time. The large autocatalytic introns and RNA processing machines discovered by Tom Cech, Sid Altman, and Phil Sharp underscored the key roles played by noncoding RNAs in metabolism. Even the ribo-regulation of chromatin was presaged by decades of methodical work in which Jeannie Lee and others showed that monsters like Xist (an RNA that is $>20,000$ nucleotides in length) can control whether we develop as males or females. Noncoding RNAs, both big and small, have long provided key insights into novel mechanisms of gene expression and metabolism, but recent discoveries have accelerated the pace of discovery and have underscored the startling ubiquity of RNA regulatory control.

\section{Discovering that RNA has elaborate tertiary structure}

Like many of my structural biology colleagues, I take great pride in our efforts to overturn the notion that RNA is a disordered mess, resembling a bowl of wet spaghetti. We have spent entire careers trying to understand and predict the rules governing formation of RNA secondary and tertiary structure. We have solved structures of biologically important RNA molecules and written algorithms to parameterize

(C) 2015 Pyle This article, published in $R N A$, is available under a Creative Commons License (Attribution-NonCommercial 4.0 International), as described at http://creativecommons.org/licenses/by-nc/4.0/. 
(Turner) and understand the physical basis for RNA form and function. The results have been visually striking: The self-splicing intron structures solved by Cech, Doudna, Strobel, and Toor, along with the RNAse P structures of Pace and Mondragon, showed RNA in an entirely new light: RNA molecules can be as architecturally complex as proteins and they can even function as enzymes. The diversity of RNA form became increasingly apparent with the discovery and structural characterization of riboswitches by Breaker, Patel, Batey, and others. High-resolution structures of ribosomes (by Noller, Ramakrishnan, Steitz, and Yonath) revealed the gigantic scale and functional complexity that is possible for machines made of RNA. RNA tertiary structures still seem to surprise the scientific community, despite dramatic progress in 20 years.

And yet RNA tertiary structure is not new. Transfer RNA was the first functional nucleic acid that we could truly "see" in detail because it was possible to isolate and purify it on a large scale. B-form DNA was but a low-resolution model until Dickerson obtained the first high resolution crystal structure of B-DNA in 1981, almost a decade after Rich and Kim unveiled the first high-resolution crystal structures of tRNAphe (starting in 1972). Images of tRNA revealed a structurally elaborate molecule that contained both A-form duplexes (secondary structural elements) and strange networks of molecular interactions involving unexpected com- binations of nucleobases and the RNA backbone (tertiary interactions).

Understanding RNA tertiary interactions - what they look like, and what they bring to the thermodynamic table, has been my passion for more than two decades. I am particularly fond of the ribose $2^{\prime}$-hydroxyl group because it can participate in so many types of stabilizing interactions, where it can function as a hydrogen bond donor, acceptor, or both. In this way, I think that the $2^{\prime}$-OH group gives RNA “special powers," enabling it to adopt unique shapes that interact specifically with proteins and other RNAs. Upon identifying my first interactions that involve the 2 -hydroxyl group (as a postdoc in the Cech lab), I believed I had discovered something fundamentally new: that RNA shape and function can be dictated by the RNA backbone and not just by base-pairings. This is still an important and (to some) a surprising idea, but a thoughtful colleague (cited at the very beginning) urged me to glance at the crystal structure of tRNA before getting too excited. And sure enough, my $2^{\prime}-\mathrm{OH}$ interactions were all there, visible in heart of tRNA, along with many others, that would be "discovered" again, years later. But that's OK. Some of the best ideas are those with a good foundation. We have seen so many game-changing breakthroughs in RNA science because the community continues to build a strong intellectual and social foundation for discovery and constructive rediscovery by successive generations of RNA believers. 

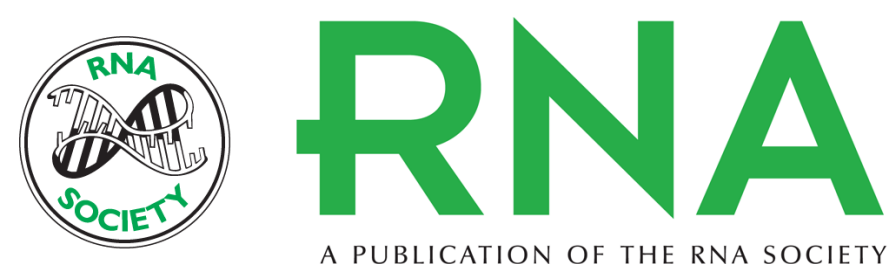

A PUBLICATION OF THE RNA SOCIETY

\section{Rediscovering RNA}

Anna Marie Pyle

RNA 2015 21: 714-715

Open Access Freely available online through the RNA Open Access option.

Creative This article, published in $R N A$, is available under a Creative Commons License Commons (Attribution-NonCommercial 4.0 International), as described at License http://creativecommons.org/licenses/by-nc/4.0/.

Email Alerting Receive free email alerts when new articles cite this article - sign up in the box at the Service top right corner of the article or click here.

To subscribe to $R N A$ go to:

http://rnajournal.cshlp.org/subscriptions

(C) 2015 Pyle; Published by Cold Spring Harbor Laboratory Press for the RNA Society 